\title{
Matching Teacher Production With National Needs In Nigeria: A Periscope
}

\author{
ABBAS, Adamu Gimba (PhD) and ABDULWAHAB, Suleiman \\ Federal College Of Education (Technical)P.M.B 60 Gombe
}

\begin{abstract}
This paper examines the relationship between national needs and teacher production in Nigeria. By so doing, it discusses the pioneering efforts of missionaries towards teacher training. The paper brings into limelight the government developmental efforts from the Colonial era to date towards the expansion, diversification and management of teacher training institutions and programmes. In spite of the government's efforts, available literature have shown that the issues of teacher quantity, quality and variety are posing serious challenges to the attainment of educational goals in Nigeria. It was concluded that unless these issues are concomitantly addressed, the nation's vision 20:2020 will remain rhetoric. It is on the basis of this that the paper recommends adequate remuneration of teachers to boost morale and improve their societal image, review of entry requirement of students and evolvement of statistical data in areas of teachers shortages, among others.
\end{abstract}

Keywords: Teacher, Production, and National Needs

\section{INTRODUCTION}

The needs of Nigeria as a nation are clearly written and echoed in its vision statement that:By the year 2020, Nigeria will have a large, strong, diversified, sustainable and competitive economy that effectively harnesses the talents and energiesof its people and responsibly exploits its natural endowments to guarantee a high standard of living and quality of life to its citizens (FGN, 2010:3). A major strategy proposed by the government towards the attainment of the vision is to invest in human capital and to transform the Nigerian people into active agents for growth and national development (FGN, 2010). The viability of this strategy depends largely on the provision of sound and functional education to the vast Nigerian populace. It is globally acclaimed that sound education is the bedrock for all sustainable developments and transformations (FGN, 2004; Durosaro, 2006 \& Ejima, 2012). Teachers are unequivocally placed at the center of all education systems. It is the teacher that translates the curriculum, harnesses the instructional materials, creates a stimulating classroom environment, uses appropriate teaching techniques, provides necessary guide to students and obtains positive feedbacks to bring about a desirable change in learners' behaviors. Teachers are solely responsible for the implementation of new educational ideas, policies and knowledge at the classroom level. Jibril(2007) maintains that whatever input is made into an education system will be of little avail if the teacher is unskilled, poorly trained or even ignorant. Synonymous to the word teacher is instructor, trainer, mentor, educator, master, guru, lecturer, tutor, don, and professor (free dictionary.com, nd).

Considering the pivotal role of teachers in educational transformation, it will not be out of place if their production is accorded top priority and utmost attention. As it is rightly put, no system of education can rise above the quality of its teachers (FGN, 2004). Equally, no nation toys with its teacher's preparation and production unless the nation is ready to embrace and battle with low productivity, high rate of unemployment, abject poverty, indiscipline, corruption, insecurity and depressed economy. Teacher production refers to the process by which an individual is trained and equipped with adequate knowledge and pedagogical skills as well as right type of values and attitudes that are necessary for that individual to positively impart and influence the behavior of a learner. Durosaro (2006) identifies two types of teacher preparation programmes in Nigeria, as pre-service and in-service. The pre-service programmes are meant to give adequate training to intending teachers while in-service programmes are refresher training given to practicing teachers towards improved professional development. Contemporarily, there is genuine interest especially in developing countries, on teacher production processes partly because of their desire to meet up with the global education standard and to keep abreast with challenging transformation of global economic processes. This piece of presentation is intended to highlight government developmental efforts towards teacher preparation and production in Nigeria, discuss challenging issues in teacher production and proffer lasting solution that will improve teacher education system. 


\section{DEVELOPMENT OF TEACHER EDUCATION IN NIGERIA}

Historically, teacher education is as old as western education in Nigeria. It is traceable to the activities of various church missions in Nigeria. Prominent among the church missions were Wesley Methodist, the Church Missionary Society, Church of Scotland and Roman Catholic who operated between 1842 and 1890. Various church missions established training institution devoted mainly to the training of elementary teachers (Durosaro, 2006; Afe, 2006\& Ejima, 2012). The first teacher training college was founded by the Christian Missionary Society (CMS) in Abeokuta in 1859. It was known as the Training Institute. It was later moved to Lagos to become an arm of a Grammar School. However, the establishment of Saint Andrew's College, Oyo in 1896 signaled a very landmark in the training of teachers in the country. The pioneering efforts of the CMS were later strengthened by other missionary societies. For instance, the Baptist Mission founded the Baptist Training College at Ogbomosho in 1897. The Wesleyan Methodist Missionary Society opened an institution to train Catechists and teachers in Ibadan in 1905 (Afe, 2006; Akindutire and Ekundayo, 2012;\& Ejima, 2012).

Obviously, before independence, teacher training was mostly in the hands of missionaries. They were able to train teachers through the pupil teacher system, a kind of apprenticeship system whereby the missionaries and pupils lived together. As the number of primary and secondary schools began to increase due to the competitive activities of various missionaries and the establishment of some schools by the then Colonial government, the demand for teachers sporadically increased. The missionary system of training teachers was criticized as unsatisfactory due to its lopsidedness in religious doctrines rather than training for professionalism.

\section{GOVERNMENT DEVELOPMENTAL EFFORTS TOWARDS TEACHER PRODUCTION IN NIGERIA.}

Shortly before independence and up to date various governments had in one way or the other made stringent and commendable efforts to boost the production of teachers to match demands as well as maintaining some level of quality in the production processes. Landmarks in government efforts towards teacher production in terms of quantity, variety and quality are discussed below:-

\section{Formation of Phelps-Stokes Commission}

Phelps - Stock commission of 1925 was a major step taken by the government to boost and improve teacher production in Nigeria. The report of the commission criticized the teacher training system of the missionaries describing it as unsatisfactory and gave rise to two forms of teacher education of two years duration each (Jekayinfa, 2000; Afe, 2006 \& Jibril, 2007). These were the elementary training colleges for training Grade III teachers for the junior primary schools and the higher elementary training colleges for training Grade II teachers for the senior primary schools. Any candidate willing to go for elementary training course would have served as pupil teacher for two years and on successful completion of the Grade III course had to teach again for at least two years before proceeding to the higher elementary training for the two year Grade II course.

\section{Constituting Ashby Commission:}

The commission was setup in April 1959 by the government to conduct an investigation into Nigerians need in the field of post-secondary school certificate and higher education. The commission's report observed among others that there was a gravely inadequate supply of trained and educated teachers in Nigeriansecondaryschools, to cope with an increase in demand for more of this category of education institutions. The report therefore recommended the training of more teachers for the nation's secondary schools, the establishment of more universities and faculty of education to run bachelor's degrees in Education where qualified teachers could be produced (Jekayinfa, 2000 \&Durosaro, 2006). Consequently, bachelor of art or science education degrees were first introduced by University of Nigeria, Nsukka in 1961. University of Ibadan followed suit in 1963; Ahmadu Bello University Zaria, 1964; University of Lagos in 1965, and Obafemi Awolowo University, Ile-Ife in 1967. (Jekayinfa, 2000).Today almost all the Universities in Nigeria have faculties of education where qualified teachers are produced.

\section{Establishment of Colleges of Education:}

The idea of Advanced Teachers' Colleges emerged from the recommendation of Ashby report for a twoyear Grade I Teachers College which should be associated with institutes of education of Universities (Afe, 2006). This two year proposal was modified by government to three years which gave rise to new programme and certificate - Nigeria Certificate in Education (NCE). Initially, five of these Advanced Teachers Colleges were established, at Lagos, 1962; Ibadan, 1962; later transferred to Ondo in 1964; Owerri, 1963, now Alvan Ikoku COE; Kano, 1964 and Abraka, 1968. The early Colleges were largely funded and staffed by the UNESCO (Durosaro, 2006). These Advanced Teachers Colleges later metamorphosed into what is now known as Colleges of Education (COE). A rapid establishment and expansion of these Colleges was witnessed in the 80's mainly due to the introduction of Universal Primary Education (UPE) in 1976 and the new system of education, the 
6,3,3,4. By 2014, there are 14 Private Colleges,47 State Colleges and 22 Federal Colleges, making a total of 83 accredited Colleges of Education in Nigeria (NCCE, 2009) The major trust of the Colleges is to produce competent middle level teachers in large quantity and variety for the primary and junior secondary or precisely for the lower and upper basic schools since NCE Certificate is now the minimum teaching qualification in Nigeria. In an attempt to produce teachers in varieties some colleges are devoted to the production of technical, science and vocational education teachers. A college is also dedicated to female teachers in vocational and technical education as well as in the production of teachers in special education; the education for the physically challenged individuals.

\section{Establishment of National Commission for Colleges of Education (NCCE).}

Among the government's efforts to maintain standard and quality in teacher education was the establishment of National Commission for Colleges of Education (NCCE) in 1989 which was amended by Act 12 of 1993. (NCCE, 2009). The commission is mandated to advise the Federal Government on, and coordinate all aspects of non-degree teacher education in Nigeria. In pursue of its mandates, the commission had standardized and continuously reviewed the curriculum of the Colleges of Education. This constant review of the curriculum had strengthened the capacity of Nigeria Certification in Education (NCE) graduates. After the laying down of the minimum requirements for the Colleges, the Commission had gone ahead to accredit their courses. The accreditation of the courses is carried out once in five years. The commission is amajor stake holder in the production of teachers required for the successful implementation of UBE in Nigeria. In its attempt to coop with this challenge, the commission, knowing that NCE is the minimum teaching qualification, has seen to the establishment of more colleges and diversification of NCE programmes. Notably, is the mounting of Primary Education Studies (PES) and Early Child and Childhood Education in almost all Colleges of Education in Nigeria. The commission has to its credit 83 approved Colleges of Education.

\section{Establishment of National Teachers Institute (NTI)}

In line with government commitment to teacher education, the National Teachers' Institute was established in 1976 with its base in Kaduna, Northern Nigeria. The NTI is a single mode distance education institution in Nigeria dedicated to in-service education for teachers. It is mandated to provide courses of instruction leading to the development, upgrading and certification of teachers as specified in the relevant syllabus using Distance Education Techniques.The Institute since inception mounted six teacher training programmes by Distance Learning System all aimed at uplifting the quality of teachers in Nigeria (NTI, 2009). The programmes and dates of commencement are:-

i. The teacher Grade II Certificate (TC II by DLS) 1982 to 2006, focused on teachers that had lower than the TC II.

ii. The Nigeria Certificate in Education (NCE by DLS), 1990 to Date, ensures that graduates of TC II upgrade themselves to NCE which is the minimum teaching qualification in Nigeria.

iii. The Pivotal Teacher Training Programme (PTTP by DLS), 2000 to 2003 also trained teachers that had below the TC II.

iv. Postgraduate Diploma in Education (Affiliated to Usman Dan Fodiyo University, Sokoto), 2005 to Date, an 18 month training in pedagogy for graduate teachers without teaching qualification.

v. Advanced Diploma in Education (In School Supervision and Inspection, Early Childhood Education and Guidance and Counseling), 2005 to date provides 18 months training.

vi. Special Teacher Upgrading Programmes (STUP), 2007 to date, is an intensive 2year programme aimed at fast-tracking the attainment of the national goal of making NCE the minimum teaching qualification.

\section{Establishment of Teacher Registration Council.}

In response to the yearning and agitation of prominent teaching personalities in Nigeria, on professionalization of teaching, the federal government established the Teachers Registration Council of Nigeria (TRCN) through Act 31 of 1993. The council finally became operational by June 2000 with the appointment of a Registrar (TRCN, 2005). It is believed that when teaching is made a profession, there will be serious sanity in practices and remunerations of teachers. The council is charged with the responsibilities of teacher's registration, accreditation, certification, promotion, development, discipline and making regulations to control the practice of teaching as a profession. The council has State offices all over the federation.

\section{CHALLENGING ISSUES IN TEACHER PRODUCTION IN NIGERIA.}

In spite of government developmental efforts towards teacher production in Nigeria, the issues of teacher quality, quantity and variety are posing serious challenges to educational advancement of the nation. Among the objectives of teacher education in Nigeria is to produce highly motivated, professionally trained, intellectually 
capable and efficient classroom teachers. The level of attainment of this objective is subject to everybody's judgment. However, some recent literature have illuminated on the intensity of teachers' quality in Nigeria. Of particular interest is the situation in Kaduna State. Durosaro (2013) reported that a total of 1,599 teachers selected from across the state were given primary four (4) test in mathematics and basic literacy. One of them scored 75percent, 250 scored between 50 to $75 \%$ and 1,300 scored below 25percent. The Chairman of the State House of Assembly Committee on education, Yunusa Muhammed said out of 36,000 teachers in the State, 15,000 are not qualified.Similarly, in Kwara State, an aptitude and capacity test was organized for a total of 19,125 teachers in the State's public schools in 2008. Out of these 2,628 were university graduates. The teachers were given tests that were designed originally for primary four (4) pupils in English and Mathematics. At the end of the exercise, only seven teachers out of the 19,125 crossed the minimum aptitude and capacity threshold. Only one out of the 2,628 graduate teachers passed the test, 10 graduates scored outright zero. The teachers fared worse in literacy assessment which recorded only 1.2 percent pass rate. In 2006 as reported by Maureen (2014), the former Minister of Education, Oby Ezekwesili said that 40 percent of teacher in service were not qualified. Also, Aminu Sharehu, director general of NTI, inline with the ministers statement said that over 80percent of teachers in Northern Nigeria are not qualified due to lack of motivation. The recent threats of some governors to sack incompetent teachers might not be unconnected with their apparent lack of quality. For example, in July 2009, Plateau State government sacked about 6000 teachers. Eboyin State in June, 2010 suspended 26 teachers. Imo State government in November 2012, also threatened to sack any teacher found to be incompetent. Governor Adams Oshiomole recently sacked some teacher for dereliction of duty. The incidence of unqualified teachers permeates all levels of education in Nigeria. Many individuals have equally lost faith in the quality of education offered by Nigerian universities. The mass exodus of undergraduate students to study abroad is a convincing pointer to this assertion. Laitan (2013) reported that Nigeria was the third Non-European Union country that sends the highest number of students to United Kingdom, ranking only behind India and China. This excludes other students in United States of America, Canada, Singapore, Malaysia, Hungary, South Africa and Ghana. It is disheartening when one realizes that many of these students might not comeback to the country to put in their best. The commencement of Universal Basic Education (UBE) is already having a spontaneous effect on the quantity of teachers in Nigeria. Inspite of government's efforts to produce and upgrade more teachers though expansion of teacher training institutions, the quantity of available teachers remains a challenge.In 2009, the Federal Ministry of Education, roadmap to transformation reported that a total of 969,078 teachers would be needed for the early childhood and care education and 338,147 others for the primary education subsector. Furthermore, a total of 12,329 teachers would also be needed for the nomadic education sub-sector and 581 others for Junior Secondary Education Sub-sector. This brings the total of overall teacher shortage at the basic education level to 1,320,135 across the country. Looking at the Colleges' production capacity of 64,000 teachers per annum, it would take Nigeria 20years to bridge the gab. This report was equally buttressed by the executive secretary of NCCE Prof. Junaid, while delivering his speed at the $35^{\text {th }}$ pre-convocation lecture in F.C.E(T) Akoka, Lagos (Agency Reporter, 2012).In concomitance to teachers' shortages, Osuji, the Policy Adviser of Civil Society Action Coalition on Education for All lamented that Nigeria needs to recruit atleast 200,000 teachers by 2015 to achieve Education for All (EFA) target. She said this while marking the Global Action Week in Abuja (PM News, 2013). The shortage of teachers in schools is equally peculiar to tertiary institutions in Nigeria. In a study conducted by the United States Embassy in Nigeria, it was revealed that there are academic staff shortages in all areas particularly in the critical areas of science and technology. In addition, over 60percent of academic staff in Nigerian Universities system is in the category of Lecturer I and below due to inter and intra sector brain drain (United States Embassy, 2012). The perennial problem of teachers' shortages is aggravated by poor remunerations given to teachers as well as insensitivity of the government at various levels to employ adequate teachers. Many experienced or trained teachers leave teaching for more lucrative jobs like Police, Civil Defense, Customs, Road Safety, Immigration, Bank, National Drug and Law Enforcement Agency (NDLEA) and other private industries. This explains why females continue to dominate teaching at lower and upper basic education. The problem of quality might be attributable to the kind of students admitted into the teacher education programmes, the low status accorded to teachers, the low admission requirements and the unethical activities inherent in various teacher upgrading programmes mounted by NTI distance learning system and its associates. Teachers' shortages by variety is partly compounded by poor enrolment of students and chiefly by paucity of statistical data on areas of teacher shortages from basic to higher education levels. All these problems need to be addressed, if the country is aspiring to actualize it educational goals.

\section{SUGGESTIONS FOR IMPROVEMENT}

In order to ameliorate the persistent incidence of teachers' quality, quantity and variety in Nigeria, the following suggestions are hereby proffered.

\section{Adequate Remuneration of teacher at all levels}


Teachers deserve to be remunerated adequately in order to boost their morale and their image in the society, particularly, the primary and secondary school teachers. Some allowances can be incorporated into their salaries to serve as incentives. For instance CA, marking, exam and learner-ship allowances.

2. Recruitment of more teachers and improvement of Federal Teachers' Scheme.

There are many unemployed teachers on ground due to insensitivity of the government to teachers' shortages in schools. Many State governments are running away from increasing their workers' base to save money for political activities. This attitude should be discouraged especially when it concerns teachers. The federal teachers' scheme should be strengthened by making the teachers allowance available on time.

3. Maintain Standard Entry Requirement

Entry requirement of teacher training institutions need to be standardized. It should not be less than five (5) credits including Mathematics and English. Pre-NCE programme should be scrapped and be replaced by remedial programme.

4. Re-position the In-service teacher training programmes

All in-service teacher training programmes such as PGDE, and NCE part-time must be offered within universities and colleges. Duration for PGDE should not be less than four (4) semesters, while that of NCE part time should not be less than eight (8) semesters. The essence of this is to discourage unethical activities inherent in distance learning programmes.

5. Increase Scholarship Incentives on Teacher Education

The incentive given to student-teacher trainees in form of Scholarship should be increased to boost students' enrolment.

6. Evolve Statistical Data on Teacher Areas of Need.

There is the need to always make available statistical data on teachers' areas of shortages so that admission of students and recruitment of teachers can be tailored.

7. Increase Funding of NCCE Activities

The funding of NCCE activities is crucial to the improvementof quality of teachers in Nigeria. Increased fund is required for efficient review of curriculum, accreditation, monitoring, supervision of programmes as well as collation and distribution of statistical data on colleges.

8. Professionalize Teaching through TRCN

Teaching should be made and treated as profession. The Teachers Registration Council should be given the power to effect this. National Teachers Institute (NTI) can be made an institution under TRCN for professional training, examination and certification of teachers at all levels.

\section{CONCLUSION}

It is globally acclaimed that teachers are the pivot of all education systems. Consequently, serious attention must be given to their preparation and production if the country is aspiring to advance educationally .The pioneering efforts of the missionaries towards teacher production in Nigeria are being strengthened by the government since independence to date through rapid expansion and diversification of teacher training institutions and programmes.Inspite of all these, the incidence of teacher quantity, quality and variety is posing serious challenges to the attainment of educational goals in Nigeria. Unless these issues are concomitantly tackled, the vision 20:2020 of the nation will remain rhetoric. It is on the basis of this that some suggestions are made.

\section{REFERENCES}

[1] Adegbesan S.O. and Ghadamosi, L. (2009). Teach production, utilization and turnover patterns in the primary school education system in Nigeria. Middle East Journal of Scientific Research, 4, (4); 323-328.

[2] Afe, J.O. (2006). Reflections on becoming a teacher and the challenges of teachereducations. Inaugural Lecture Series 64. University of Benin, Nigeria.

[3] Ajeyalemi, D. (2007). The Issues of quality and quantity in Nigeria's teacher educationsystem. Retrieved from www.data.up.ac.zal/archibe 2007pdf.Pp 1-5

[4] Akindutire, I.O. and Ekundayo, H.T. (2012). Teacher education in a democratic Nigeria: Challenges and the way forward. Educational Research, 3, (5); 429-435

[5] Durosaro, D.O. (2006). Teacher education in Nigeria. Past, present and future challenges. The Pacesetter Journal of Oyo State College of Education 13, (1); 43-53.

[6] Durosaro, D.O. (2013). Teachers: The problem of quality and quantity. Retrieved from https://www.unilorin.edu.ng./publication on 13th Dec., 2014.

[7] Ejima, O.S. (2012). Teacher Professional development in the 21st century Nigeria: Thejourney, the potholes and the patches. Global Voice of Educators, 1,(1), $1-6$.

[8] FGN/Federal Government of Nigeria, (2004). National policy on education (4th edition). Lagos:NERDC Press 
[9] FGN/Federal Government of Nigeria, (2010). Nigeria vision 20:2020: Abridgedversion. FGN: 12th Dec., 2010. Pp $1-29$

[10] Jekayinfa A.A., (2000). Development of teacher education in Nigeria. Available at www.unilorin.edu.ng.pdf

[11] Jibril, M.A. (2007). Teacher education in Nigeria: An overview.African Journal on Line, 1, (2). 116-124. Available at www.ajol.info.

[12] Laju, A and Josephine, M. (2013). Teaching ranks highest employing profession in Nigeria. Vanguard. Tuesday 9th, December, 2014.

[13] Laitan, E. (2013). Nigeria Education Conundrum.Sahara Reporters, Jan., 04 2013. Maureen, C. (2014). Teacher education quantity without quality. Realnews magazine. net.

[14] Matilda J.I. (2011). Constraints in teacher education and effect on teaching and schools. Journal of Educational and social research, 1, (3), 25-30.

[15] NCCE (2009). List of colleges of education in Nigeria. NCCE. Availableat www.ncceonline.edu.ng/colleges.php

[16] NTI/ National Teachers Institute, (2010). Brief on NTI, Kaduna, Nigeria. Availableat www.icde.org.pdf

[17] PM News (2013). Education for All: Nigeria needs 200000 teachers. Availableat www.pmnewsnigeria.com>lyfestyle>Education

[18] TRCN/Teacher Registration Council, (2005). Teacher handbook. Abuja: TRCN. Availableat www.trcn.ng.gov.

[19] United States Embassy in Nigeria (2012). Nigeria education fact sheet. Availableat http://nigeria.usembassy.gov 